\title{
$\underline{\mathrm{O} J \mathrm{ED}}$
}

Volume 5, Issue 1 (2020), pp. 190-199

International Journal of

Multidisciplinary Perspectives in Higher Education

ISSN: 2474-2546 Print/ ISSN: 2474-2554 Online

https://ojed.org/jimphe

\section{COVID-19 and Black Lives Matter: Examining Anti-Asian Racism and Anti-Blackness in US Education}

\author{
Divya Anand \\ Cambridge College, Massachusetts, USA \\ Laura M. Hsu \\ Merrimack College, Massachusetts, USA
}

\begin{abstract}
The intersection of COVID-19 and the murder of George Floyd has refocused attention on the hitherto hidden, but pervasive, impacts of race and racism in the US. As this essay will argue, examining anti-Asian racism and anti-Blackness in the context of COVID-19 and Black Lives Matter movement, allow a deeper understanding of how white supremacy operates in institutions of higher education and in US society. While universities have a critical role and responsibility to spearhead transformative justice and change, racial capitalism is still at work, whereby profits are prioritized over delivering equitable educational experiences for students and the health of all its constituents. School closures in spring 2020 and reopening plans for fall 2020 are used to illustrate racial capitalism in higher education.
\end{abstract}

Keywords: Anti-Asian Racism, Anti-Blackness, Black Lives Matter, COVID-19, Higher Education, Model Minority Myth, Racial Capitalism, White Supremacy

The surge of COVID-19 and resurgence of the Black Lives Matter (BLM) movement due to a continuum of murders and use of excessive force on unarmed Black and Brown bodies-most recently George Floyd, 
Breonna Taylor, Jacob Blake, and Deon Kay-and primarily by white police officers, has brought the United States to a moment of racial reckoning. These events reveal the impact of white supremacist systems and racism in every walk of US society, including education spaces, where students of color are more vulnerable to discrimination and more often experience inequitable access to education. Most higher education institutions have ostentatiously committed themselves to antiracism efforts, and yet, there has been little evidence to show actual change in the institutional power structures in addressing systemic racism. In this regard, distinguishing between racism, Sinophobia, anti-Asian racism and antiBlackness allow for a closer scrutiny to expose overt and covert white supremacist structures and the ways they manifest in education settings. School closures due to COVID-19 and fall reopening plans offer two illustrations to further understand how this distinction and the notion of racial capitalism exposes structural inequities and white supremacy. Originally coined by Cedric J. Robinson (1983), racial capitalism centers the systemic ways in which capitalism continues to create and sustain racial inequities.

Starting in February 2020, widespread transmission of COVID-19 in the US led to school building closures, affecting at least 50.8 million public school students (Education Week, 2020), and over 1,100 colleges and universities in all 50 states cancelled in-person classes or shifted to onlineonly instruction (Smalley, 2020). In higher education, the sudden school closures meant for some students, lost housing, income, and food, as well as repercussions for student loan debts and financial aid. International students experienced additional barriers (Smalley, 2020). Community colleges, tribal colleges, and Historically Black Colleges and Universities (HBCUs) were further impacted, with the majority of students they serve affected by socioeconomic barriers that put them at a higher risk of contracting COVID19 (Mccaskill \& King, 2020). Data from the Centers for Disease Control and Prevention show that Latinx and African-American residents are three times more likely to become infected than their white neighbors, and are nearly twice as likely to die from the virus as white residents (Oppel Jr. et al., 2020). This unequal impact is due to systemic racism that historically denied access to healthy environments and the entrenched bias within healthcare and housing systems. For the African American community, the continued impact of enslavement, redlining, and Jim Crow laws is how racial capitalism works to have a fundamental impact on health inequities in the time of COVID-19 (Pirtle, 2020). The concept of racial capitalism offers valuable insights in understanding anti-Blackness and anti-Asian racism embedded within school closures and reopenings due to COVID-19.

Conversely, pledging commitment to antiracism efforts following George Floyd's murder and the fall reopening plans of many institutions, unravel the many gaps in addressing racism and systemic change. Antiracist 
efforts, limited to statements, resources, and even curriculum changes, fall short in examining institutions as systems--questioning who holds power and what values they uphold. When we consider the fall reopening plans of many Ivy League institutions, profits seem to outweigh the delivery of equitable educational experiences and the health of all constituents. Across institutions of higher education, the dilemma between starting classes in person to remain financially viable versus laying off faculty and staff with reductions in enrollment, speaks to a larger question of capitalism or, more aptly, racial capitalism. The costs of classes being borne unfairly by students choosing in-person learning formats, should classes shift to remote format, raises the question as to how far institutions will go in terms of actually changing inequitable systems. Schools such as Harvard and Yale University, where students pay the same tuition amount for in person and remote instruction, without options to get refunds if classes go remote (Carey, 2020; Kristoffersen, 2020), point to how finances influence decisions. The import of such decisions also varies across tribal and community colleges, public and private universities, and the students they serve (Harper, 2020).

Another outcome of COVID-19 is a resurgence of Sinophobia in the US. The "Stop AAPI Hate Reporting Center" (2020) recorded more than 2300 reports of racist incidents against AAPI, including micro-aggressions, bullying, harassment, hate speech, and violence since January 2020. News outlets such as CNN initially referred to the virus as the "Wuhan virus" (Griffiths \& Gan, 2020) and the "Chinese coronavirus" (Christensen \& Senthilingam, 2020). In addition to using the same references, President Trump refers to COVID-19 as the "kung flu" (Nakamura, 2020). Such insensitive references serve to ascribe blame and justify discrimination against Asians. UC Berkeley, which has 34\% Asian and Pacific Islander students ("UC Berkeley Quick Facts," 2020), came under scrutiny when its health services initially listed xenophobia as a "common" reaction to COVID-19. After much backlash, the post was taken down (Chiu, 2020).

Sinophobia at "the intersection of fear and hatred of China" (Billé, 2015 , p. 10) is a throwback to the sentiments that sanctified the Chinese Exclusion Act of 1882, which denied entry to Chinese immigrants to the US and the "yellow peril" stereotype that has plagued east Asians immigrating to the US for centuries: That they are dirty, disease-infested people who cannot be trusted (Tessler et al., 2020). Unsurprisingly, these are categorizations that remain at the root of anti-Black racism as well. AntiAsian sentiments and acts were then disproportionately borne by those who look phenotypically Chinese. The recording of racist acts as anti-Asian incidents than Sinophobic incidents towards the beginning of the pandemic (Lee, 2020; Pan, 2020; Pomfret, 2020) obscures the disparate impact of COVID-19 racism within Asian American communities. Recent immigration restrictions curtailing legal immigration and the rescinded attempt to send back international students taking online courses (Trump, 
2020) are part of a larger, insidious move to use the pandemic to expand on racist immigration policies. Another flaw in this homogenization of Asian Americans is the lack of awareness about the unequal impact of COVID-19 within Asian communities. For example, in California, Filipino Americans had a $40 \%$ mortality rate among Asian Americans in comparison to 3.3\% US mortality rates, despite being only $25 \%$ of the state's population (Wong, 2020). In contrast, for Indian Americans, job losses, financial worries, and the immigration ban were the primary stressors in the wake of COVID-19 (Kumar, 2020).

The distinction of Anti-Asian and Sinophobic racism is also important to unpack the myth of the model minority. Coined by Yuji Ichioka and Emma Gee in 1968, the term "Asian American" was meant to mobilize a collective identity to combat orientalist definitions and racial injustice (Kambhampaty, 2020). Soon, the model minority myth, the overgeneralization that Asian Americans achieve universal educational and occupational success, rose to prominence (Poon et al., 2016). The myth suggested Asian Americans were intelligent, quiet and obedient, and capable of overcoming disadvantages through strong family values and hard work. They were also considered "averse to challenging authority, adaptive, assimilationist, demure, shy, and isolated," (Yi et al., 2020, p. 20), which made them "models" for other minorities. This myth homogenizes Asian Americans as a uniform group disregarding the different histories of oppression, resources, and opportunities with which sub-groups of Asian Americans immigrated and contributes to racial exclusion from research, policy, and practice considerations that might better support distinct Asian American communities in education. It has also been used as a political tool by white supremacists to invalidate claims of systemic racism against nonAsian American People of Color and has advanced the deficit orientation that communities of color were to blame for inequalities in the first place (Yi et al., 2020). The recent Justice Department's charge against Yale University discriminating against Asian and white students in violation of civil rights law (Hartocollis, 2020), and the 2014 lawsuit filed by Asian American students against Harvard University's affirmative action, funded by right-wing activist Edward Blum, is an "example of how white power perpetuates anti-Blackness within Asian communities at the expense of Black people" (Ramirez, 2020, para. 7). Conversely, examining antiBlackness allows scrutiny of "affirmative action" in terms of the inclusion of Black people, both as faculty and students, and how the "inclusion" of non-Black People of Color can be weaponized to exclude Black people.

In educational institutions, Jared Sexton's (2008) analysis of multiracialism in relation to anti-Blackness is useful to consider how schools pit the academic success of (some) Asian American students against and above the academic difficulties of Black students. Here, schools can be celebrated as diverse despite the 
absence of Black students in the building and / or in the higher academic tracks. (Dumas, 2016, pp. 16-17)

Taking note of the complicity of Tou Thao, a police officer of Hmong ethnicity, in the murder of George Floyd (Westerman et al., 2020), endorses the need to distinguish between racism and anti-Blackness, and to uncover how white supremacy invisibly operates within Black Indigenous People of Color (BIPOC) communities. Anti-Blackness lies at the core of the many Asian Americans opposing the Black Lives Matter protests as "looting and rioting" (Mishra, 2020) and conforming to the model minority stereotype.

Further illustrating the outcomes of anti-Blackness, William A. Smith (2004) introduced the conceptual framework of racial battle fatigue, "a response to the distressing mental/emotional conditions that result from facing racism daily" (p. 180) in both education and in society at large. The impact of COVID-19 and heightened levels of stress following George Floyd's murder further exacerbated the disparity in impact on BIPOC students and faculty. One of the first surveys of a USA-wide sample of 725 full-time college students on COVID-19-related experiences in Spring 2020 revealed that of the $9.2 \%$ who experienced discrimination in the sample, 65.7\% were Asian/Asian American (Cohen et al., 2020). A community sample of the Household Pulse Survey distributed by the US Census (2020) indicated that the demonstrations and debate following George Floyd's murder has exacted a disproportionate emotional and mental toll, with rates of anxiety and depression almost triple for Black people and Asian Americans in comparison to white and Latinx Americans (Fowers \& Wan, 2020). A recent study measuring the impact of publicized incidents of police violence on "racially underrepresented" college students at various colleges and universities in the U.S. showed that students displayed symptoms consistent with post-traumatic stress disorder (Campbell \& Valera, 2020). The invariant nature of how racial stressors affect BIPOCs points to the crucial need to distinguish between racism and anti-Blackness. Comparing these research findings with both spring closures and fall reopenings in 2020, and the racial toll experienced by BIPOC students, staff, and faculty, vis-a-vis those who profit from those decisions, reveal the ways in which racial capitalism operates in higher education.

The current moment of racial reckoning highlights the urgency for non-Black People of Color to build solidarities with the Black Lives Matter movement in resisting racist tropes, exposing inequities, and demanding reparations. Shared experiences of othering and racism in the wake of COVID-19 has created a common ground of solidarity that Asian Americans and African Americans can forge against white supremacy. The rise of movements, such as Asian Americans Advancing Justice, Asians for Black Lives Matter, and Letters for BLM addressing Asian American family circles spearheaded by students of Asian descent, point to a changing 
dynamic within the community to break away from the model minority stereotypes underpinned by anti-Blackness.

Within institutions of higher education, efforts to spearhead antiracism through training, hiring practices, and revisiting curricula-while welcome-does not negate the fact "that most presidents, senior administrators, and trustees/regents at colleges and universities are white" (Harper, 2020, "Racialization of Input" section). Reopening plans, especially with in-person options, place the highest risk of loss on constituents of color, from loss of tuition to loss of life, as did school closures due to COVID-19. Financial trouble exacerbated by COVID-19 closures and the lack of federal funding, have had devastating consequences for tribal and community colleges, again disparately affecting communities of color (Bull \& Goldrick-Rab, 2020; Jaschik, 2020). Moving beyond antiracism, which is often educational for white constituents, it is important to integrate ethnic studies and cultures of the global majority to decolonize and counteract white supremacist epistemologies. Scrutinizing the ways in which racism and capitalism entwine to sustain white supremacy in institutions of higher education is important for understanding, countering and reinventing a new system where each person is valued equally. Mobilization of coalitions among BIPOCs and those who support such efforts across faculty, students, and staff is an important step towards equality in higher education spaces.

\section{References}

Billé, F. (2015). Sinophobia: Anxiety, violence, and the making of Mongolian identity. University of Hawai'i Press.

Bull, C. C., \& Goldrick-Rab, S. (2020, September 3). Tribal colleges, lifeline to rural and disenfranchised Native communities, need our help more than ever. Hechinger Report. https://hechingerreport.org/opinion-tribal-colleges-lifeline-to-ruraland-disenfranchised-native-communities-need-our-help-more-thanever/

Campbell, F., \& Valera, P. (2020). "The Only Thing New is the Cameras": A study of US college students' perceptions of police violence on social media. Journal of Black Studies, 1-17. doi: $10.1177 / 0021934720935600$

Carey, K. (2020, July 8). What Harvard and your local community college have in common. The New York Times. https://www.nytimes.com/2020/07/08/upshot/virus-collegesharvard-reopening.html

Chiu, A. (2020, January 31). 'Stop normalizing racism': Amid backlash, UC Berkeley apologizes for listing xenophobia under 'common reactions' to coronavirus. Washington Post. 
https://www.washingtonpost.com/nation/2020/01/31/berkeleycoronavirus-xenophobia

Christensen, J., \& Senthilingam, M. (2020, February 18). Coronavirus explained: What you need to know. CNN. https://www.cnn.com/2020/01/20/health/what-is-coronavirusexplained/index.html

Cohen, A. K., Hoyt, L. T., \& Dull, B. (2020). A descriptive study of Coronavirus Disease 2019-related experiences and perspectives of a national sample of college students in Spring 2020. Journal of Adolescent Health. https://doi.org/10.1016/j.jadohealth.2020.06.009

Dumas, M. J. (2016). Against the dark: Antiblackness in education policy and discourse. Theory into Practice, 55(1), 11-19. doi: 10.1080/00405841.2016.1116852

Education Week (2020, July 1). The Coronavirus spring: The historic closing of U.S. https://www.edweek.org/ew/section/multimedia/the-coronavirusspring-the-historic-closing-of.html

Fowers, A., \& Wan, W., (2020, June 12). Depression and anxiety spiked among black Americans after George Floyd's death. Washington Post. https://www.washingtonpost.com/health/2020/06/12/mentalhealth-george-floyd-census/ arc404=true

Griffiths, J., \& Gan, N. (2020, January 22). China confirms Wuhan virus can be spread by humans. https://www.cnn.com/2020/01/21/asia/china-china-coronavirussars-intl-hnk/index.html

Harper, S. (2020). COVID-19 and the racial equity implications of reopening college and university campuses. American Journal of Education, 127. https://www.journals.uchicago.edu/doi/full/10.1086/711095

Hartocollis, A. (2020, August 13). Justice Dept. accuses Yale of discrimination in application process. New York Times.

Jaschik, S. (2020, August 17). A tough year for community colleges. Inside HigherEd.https://www.insidehighered.com/admissions/article/2020/ 08/17/community-colleges-have-tough-year-enrollments

Kambhampaty, A. P. (2020, May 22). In 1968, these activists coined the term 'Asian American'-and helped shape decades of advocacy. TIME magazine. https://time.com/5837805/asian-american-history/

Kristoffersen, M. (2020, June 20). Fall 2020: More than half Yallies consider time off if classes go online. Yale Daily News. https://yaledailynews.com/blog/2020/06/20/fall-2020-more-thanhalf-of-yalies-consider-time-off-if-classes-go-online/

Kumar, R. S. (2020, May 7). Coronavirus turning Indians' American dream sour. 
https://www.americanbazaaronline.com/2020/05/07/coronavirusturning-indians-american-dream-sour-440997/

Lee, B. (2020, February 18). How COVID-19 coronavirus is uncovering Anti-Asian racism. Forbes Magazine. https://www.forbes.com/sites/brucelee/2020/02/18/how-covid-19coronavirus-is-uncovering-anti-asian-racism/\#2cdf867629a6

Mccaskill, N. D., \& King, M. (2020, July 27). For HBCUs, the coronavirus pandemic hits especially close to home. Politico. https://www.politico.com/news/2020/07/27/hbcus-reopeningcoronavirus-380753

Mishra, K. (2020, July 20). My fellow Asian Americans, we need to stand in solidarity with Black Lives Matter. Self. https://www.self.com/story/asian-american-black-americansolidarity

Nakamura, D. (2020, June 24). With 'kung flu,' Trump sparks backlash over racist language--and a rallying cry for supporters. Washington Post. https://www.washingtonpost.com/politics/with-kung-flu-trumpsparks-backlash-over-racist-language--and-a-rallying-cry-forsupporters/2020/06/24/485d151e-b620-11ea-aca5ebb63d27elff story.html

Oppel Jr., R. A., Gebeloff, R., Lai, K. K. R., Wright, W., \& Smith, M. (2020, July 5). The fullest look yet at the racial inequity of coronavirus.

https://www.nytimes.com/interactive/2020/07/05/us/coronaviruslatinos-african-americans-cdc-data.html

Pan, D. (2020, January 30). Fears of coronavirus fuel anti-Chinese racism. The Boston

Globe. https://www.bostonglobe.com/2020/01/31/metro/fears-coronavirusfuel-anti-chinese-racism/

Pirtle, W. N. L. (2020). Racial capitalism: A fundamental cause of novel coronavirus (COVID-19) pandemic inequities in the United States. Health Education \& Behavior. https://doi.org/10.1177/1090198120922942

Pomfret, J. (2020, February 6). The coronavirus reawakens old racist tropes against Chinese people. Washington Post. https://www.washingtonpost.com/opinions/2020/02/05/coronavirusreawakens-old-racist-tropes-against-chinese-people/

Poon, O., Squire, D., Kodama, C., Byrd, A., Chan, J., Manzano, L., Furr, S., \& Bishundat, D. (2016). A critical review of the model minority myth in selected literature on Asian Americans and Pacific Islanders in higher education. Review of Educational Research, 86(2), 469502. https://doi.org/10.3102/0034654315612205

Ramirez, R. (2020, June 3). Asian Americans need to talk about antiBlackness within our communities. Vox. https://www.vox.com/first- 
person/2020/6/3/21279156/george-floyd-protests-police-brutalitytou-thao-asian-americans

Robinson, C. (1983). Black Marxism: The making of the Black radical tradition. University of North Carolina Press.

Sexton, J. (2008). Amalgamation schemes: Antiblackness and the critique of multiracialism. University of Minnesota.

Smalley, A. (2020, July 7). Higher education responses to coronavirus (COVID-19). National Conference of State Legislatures. https://www.ncsl.org/research/education/higher-educationresponses-to-coronavirus-covid-19.aspx

Smith, W. A. (2004). Black faculty coping with racial battle fatigue: The campus racial climate in a post-Civil Rights era. In D. Cleveland (Ed.), pp. 171-190, A long way to go: Conversations about race by African American faculty and graduate students. Peter Lang.

Stop AAPI Hate (2020). Asian Pacific Policy \& Planning Council. http://www.asianpacificpolicyandplanningcouncil.org/stop-aapi$\underline{\text { hate/ }}$

Tessler, H., Choi, M., \& Kao, G. (2020). The anxiety of being Asian American: Hate crimes and negative biases during the COVID-19 pandemic. Am J Crim Just. https://doi.org/10.1007/s12103-020$09541-5$

Trump, D. J. (2020, June 22). Proclamation suspending entry of aliens who present a risk to the U.S. labor market following the coronavirus outbreak. The

White

House.

https://www.whitehouse.gov/presidential-actions/proclamationsuspending-entry-aliens-present-risk-u-s-labor-market-followingcoronavirus-outbreak/

UC Berkeley Quick Facts, Fall 2019 Enrollment (2020). Berkeley Office of Planning and Analysis. https://opa.berkeley.edu/campus-data/ucberkeley-quick-facts

U.S. Census Bureau (2020). Week 5 Household Pulse Survey: May 28 - June 2. Table 2a. Symptoms of Anxiety Experienced in the Last 7 days, by Select Characteristics; Table 2b. Symptoms of Depression Experienced in the Last 7 Days, by Select Characteristics. https://www.census.gov/data/tables/2020/demo/hhp/hhp5.html

Westerman, A., King, N., \& Kwong, M. (2020). For one immigrant community, George Floyd's death isn't just about black and white. NPR. $\quad$ https://www.npr.org/2020/06/04/868978380/for-oneimmigrant-community-george-floyds-death-isn-t-just-about-blackand-white

Wong, T. (2020, July 21). Little noticed, Filipino Americans are dying of COVID-19 at an alarming rate. LA Times. https://www.latimes.com/california/story/2020-07-21/filipinoamericans-dying-covid 
Yi, V., Mac, J., Na, V. S., Venturanza, R. J., Museus, S. D., Buenavista, T. L., \& Pendakur, S. L. (2020). Toward an anti-imperialistic critical race analysis of the model minority myth. Review of Educational Research. https://doi.org/10.3102/0034654320933532

\section{Author Bios}

DIVYA ANAND, $\mathrm{PhD}$, is a senior faculty at the School of Undergraduate Studies, Division of Arts and Sciences, Cambridge College, USA. Her research focuses on the intersections of education and racism to propose a transformative justice approach towards systemic change. Email: divya.anand@go.cambridgecollege.edu

LAURA M. HSU, EdD, is an Associate Professor in the School of Education and Social Policy, Merrimack College, USA. Her research examines how transformative justice can be promoted in educational settings using curricular materials and mediation by educators. Email: hsul@merrimack.edu 